\title{
Global Warming Impact on the Earth
}

\author{
Pijush Kanti Bhattacharjee, Member, IACSIT
}

\begin{abstract}
Atomic properties of elements and compounds are prone to change due to fluctuation of surrounding temperature and pressure. General properties of elements and compounds are exhibiting at par with the normal temperature and pressure (NTP). As the cause of global warming, the atomic properties of elements and compounds will not behave normally as in NTP. Their characteristics and applications are subjected to evergreen changing process, since natural temperature and pressure are not remaining constant in case of global warming. Whole life pattern of the living beings will be full of complexity and not guided by any rules in case of global warming. Industries, refineries, excessive electromagnetic wave propagation through air, transport vehicles - road and airways, rapid growth of entertainment equipment like air conditioned (A.C) machine, refrigerator, television, mobile phone, computer etc are the main cause of increasing environment temperature. To solve this emerging problem, Industrialization (Industry should grow with minimum working space effecting least environment pollution) and Naturalization (Maximum portion of the earth must be covered with either agricultural green trees or clean water) have to be provided side by side and at the same time people have to minimize using all type of entertainment equipment, otherwise global warming may cause destruction of the world.
\end{abstract}

Index Terms-Atomic Properties, Industrialization, Naturalization, Normal Temperature and Pressure (NTP).

\section{INTRODUCTION}

Environmental pollution [1]-[8] is very high in the present days due to different industries (heavy and light), oil-refineries, petrochemical, vehicles - air route and surface route etc. Most of the times residue of these industries which are generally composed of different poisonous materials in gaseous form causing global warming, are either thrown out or burnt in open air after being exhausted through openings of a long heighten chimney [5], [8]. Global warming means increase in world's surface and environment temperature due to greenhouse effect. The greenhouse gas is composed of carbon dioxide and monoxide $\left(\mathrm{CO}_{2}, \mathrm{CO}\right)$, nitrogen oxide $\mathrm{NO}_{\mathrm{x}}$, Chlorofluorocarbons (CFC), sulphuric fluoride, methane, hydrocarbons, water vapor etc.

The Intergovernmental Panel on Climate Change (IPCC) has estimated that the earth's temperature will rise 1 to 3

Pijush Kanti Bhattacharjee is an Assistant Professor in the Department of Electronics and Communication Engineering, Bengal Institute of Technology and Management, Santiniketan, P.O. Doranda, West Bengal, Pin-731236, India. He is an Ex Asssitant Director in the Department of Telecommunications (DoT), Government of India, India. He is a Member of IE, ISTE, IAPQR, IIM, ARP, India; CSTA, USA; IACSIT, Singapore and IAENG, Hongkong.

(Phone No: +91-33-25954148, Email: pijushbhatta_6@hotmail.com) degrees in centigrade in the coming decades. Thus global warming is enhancing the extreme environment temperature rise and at the same time to uplift water in the sea level by 0.5 $\mathrm{ft}$ to $5.0 \mathrm{ft}$ due to melting of mountain glaciers and expansion of the oceans. The climatologists are seriously warned for polar ice melt because of global warming and hence it creates "environmental refugees" throughout the world. According to IPCC, the sea level will rise, based on present day energy consumption pattern, in the range of $31 \mathrm{~cm}$ to $110 \mathrm{~cm}$ by 2100 A.D. Therefore suitable measures have to be taken for checking this global climate change.

\section{Global Warming CAUSE In The EnVIRONMENT}

In manufacturing industry, oil-refineries, petrochemical, chemical industries and heavy industries etc, the last residue is consisting of some sort of oil, acid, bases, hydrocarbon cycles etc which are highly poisonous and furiously affected in contact of human and biological living bodies [1]-[8]. Generally we throw or burnt these last residue gases in open air, yielding greenhouse gases. In cases of burning residue gases in open air, some part of the residue gases are not completely $(100 \%)$ burnt, remain as its original condition. These remaining residue gases or skipping off as unburnt condition i.e. in originating condition mix with natural air in environment. These unburnt residue gases or simply the residue gases with the ashes of burnt residue gases with all greenhouse gases, because of its highly poisonous character, spread numerous diseases in animals and botanic life including human one, especially in the surroundings of these industries plant (say 3 4 $\mathrm{Km}$ radius from the exposure of the residue gases or the burning residue gases) and responsible to rise environment temperature rapidly. Again while the residue gases are burnt in the open air leaving from high chimney, they consumed lot of oxygen from the surrounding medium for burning process and as a result scarcity of oxygen may happen in the surrounding medium. At the same time outcome of the burning process like ashes, carbon mono-oxide (CO), carbon di-oxide $\left(\mathrm{CO}_{2}\right)$, hydrogen sulphide $\left(\mathrm{H}_{2} \mathrm{~S}\right)$, methane $\left(\mathrm{CH}_{4}\right)$ and other poisonous compound of hydrocarbons etc are spreading all over the pick up region (say 3 4 $\mathrm{Km}$ radius) from the burning point. This is causing another harmful pollution to the nature and increase the temperature of the atmosphere causing extreme global warming.

Lot of different kind trees are generally planted surrounding in the industries for absorbing the poisonous residue materials and gases which are coming out either thrown or burnt in air the residue gases, but the trees in the surrounding area of the industries can bear the environmental pollution upto certain limit. After a certain period, the trees 
are equally affected by the diseases and reach to the saturation level of absorbing the poisonous materials and gases i.e. not being able to absorb further outcome of the residue materials. So, environmental pollution created by these industries, supplemented by the trees, is not a permanent solution for a long time basis. It requires a comprehensive holistic study and invention of different technical pollution control instruments for homogeneous global climate. Therefore the author has already designed an instrument [5], [8] to control and abolish all type of residue materials and gases from the industries.

\section{GLOBAL WARMING CONTROL AND CONCLUSION}

Global Warming causing temperature rise in environment may effect to change in the atomic properties of the elements like motion, valency, magnetism, electrostatic, conduction, electronic structure, crystalline structure, electropositivity and electronegativity etc. Also this Global Warming has a great impact on earth's magnetism, gravitation, ice meltation, sea overflow, change of weather, disease affective bacteria-virus explosion etc. Due to change of atomic nature and properties with respect to rise of temperature, human and botanic life will be highly effected and causing serious problem as nature pollution. Therefore, we have to be more careful for maintaining standard natural temperature and pressure at all places in the earth. We must create a total safe region inside the factory as well as outside the factory regarding the pollution measure. Now-a-days our life patterns are difficult one and surrounded by complexity for this global warming issue. Industries, refineries, excessive electromagnetic wave propagation through air, transport vehicles - road and airways, rapid growth of entertainment equipment like air conditioned (A.C) machine, refrigerator, television, mobile phone, computer, MP3, CD, DVD-player etc are the main cause of increasing environment temperature. Our healths with minds are not playing in a smooth natural way to offer the best output in the respective jobs.

153 nations have agreed to sign the convention on climate change in Earth Summit held at Janeiro for reducing emission of $\mathrm{CO}_{2}$ and other greenhouse gasses in 1992, last year (2009 A.D) World Climate Summit for Checking Green House Effect has been held at Copenhagen between the high profile officials of all countries like Presidents, Prime Ministers etc. Therefore to control global warming, Industrialization (Industry should grow with minimum working space effecting least environment pollution) and Naturalization (Maximum portion of the earth must be covered with either agricultural green trees or clean water) have to be provided side by side and at the same time people have to cut short all type of entertainment equipment, finding alternative sources of energy like renewable energy, manufacturing fuel or alternative fuel efficient vehicles etc. In fine, the Nobel-poet Tagore appeals "Dao phire se aranya, lao a nagar" meaning that "Give back those forests, take these cities". It signifies that our city oriented industrial life pattern is destructing natural climate and forests around us; as a result environment temperature is rising rapidly. Therefore, it is the earnest duty to maintain natural harmony and bring back trees plantation and green forests growth in full swing having the least damage by industrial wastes. By this way, global warming may be controlled or rather incautious for the coming days.

\section{REFERENCES}

[1] S. E. Manattan, Fundamentals of Environmental Chemistry, $3^{\text {rd }}$ Edition, CRC Press, 2007.

[2] N. K. Uberoi, Environmental Management, Revised Edition, Excel Books, 2002.

[3] H. S. Peavy, D. R. Rowe, G. Tchobanoglous, Environmental Engineering, McGraw Hill International Company Edition 2000.

[4] M. L. Davis and D. A. Cornwell, Introduction to Environmental Engineering, $3^{\text {rd }}$ Edition, McGraw Hill International Company, 1998.

[5] P. K. Bhattacharjee, "Environmental Pollution Control and Prevention System" Indian Engineering Congress, 2008 at Warangal, A.P, India, pp 148-150, Dec, 2008.

[6] S. V. S. Rana, Essentials of Ecology and Environmental Sciences, Prentice Hall of India Pvt. Ltd, New Delhi, 2003.

[7] G. M. Masters, Introduction to Environmental Engineering and Science, $5^{\text {th }}$ Edition, Prentice Hall of India Pvt. Ltd, New Delhi, 2001.

[8] P. K. Bhattacharjee, "Environmental Pollution Free System in All Over the World", International Journal of Environmental Science and Development, Singapore, vol. 1, no. 1, pp 57-59, April 2010.

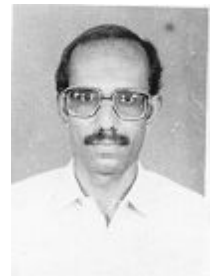

Dr. Pijush Kanti Bhattacharjee is associated with the study of Engineering, Management, Law, Indo-Allopathy, Herbal, Homeopathic and Yogic medicines. He is having qualifications ME, MBA, MDCTech, AMIE, BSc, BA, LLB, BIASM, CMS, PET, EDT, FWT, DATHRY, BMus, KOVID, DH, ACE, FDCI etc. He worked in Department of Telecommunications (DoT), Govt. of India, as an Engineer from June 1981 to Jan 2007 (26 years), lastly holding Assistant Director Post at RTEC [ER], DoT, Kolkata, India. Thereafter, he worked at IMPS College of Engineering and Technology, Malda, WB, India as an Assistant Professor in Electronics and Communication Engineering Department from Jan, 2007 to Feb, 2008 and Feb, 2008 to Dec, 2008 at Haldia Institute of Technology, Haldia, WB, India. In Dec, 2008 he joined at Bengal Institute of Technology and Management, Santiniketan, WB, India in the same post and department. He has written two books "Telecommunications India" \& "Computer". He is a Member of IE, ISTE, IAPQR, IIM, ARP, India; CSTA, USA; IACSIT, Singapore and IAENG, Hongkong. His research interests are in Medicines Therapy, Image Processing, Quantum Computing, Wireless Communications, Network Security, Nanotechnology. 